\title{
Kemampuan Literasi Matematis Space And Shape Dan Kemandirian Siswa SMA Pada Discovery Learning Berpendekatan RME-PISA
}

\author{
Urni Babys ${ }^{1)}$ \\ 1) Prodi Pendidikan Matematika STKIP SOE, NTT, Indonesia \\ E-mail:urni.babys@gmail.com
}

\begin{abstract}
Abstrak. Rendahnya kemampuan literasi matematis siswa di Indonesia mengakibatkan peringkat Indonesia pada tes PISA rendah. Hal ini juga diakibatkan karena kurangnya kemandirian siswa dalam belajar di kelas, pembelajaran yang berpusat pada guru sehingga siswa pasif dan hanya menerima informasi dari guru membuat siswa mudah lupa materi yang diajarkan terutama materi bangun ruang yang masih sangat abstrak. Penelitian ini bertujuan untuk menginvestigasi apakah kemampuan literasi matematis dan kemandirian siswa yang diajar dengan model Discovery Learning berpendekatan RME -PISA tuntas secara klasikal dan lebih baik daripada kemampuan literasi matematis dan kemandirian siswa yang diajar menggunakan model RME dan lebih baik daripada siswa yang diajar secara ekspositori. Penelitian ini termasuk penelitian semu yang menggunakan desain pretest-posttest control group. Data kemampuan literasi matematis dikumpulkan melalui tes kemampuan literasi matematis pada materi jarak dalam ruang dimensi tiga dengan soal-soal setara tes PISA, sedang data kemandirian siswa dikumpulkan dari hasil observasi selama proses pembelajaran. Temuan penelitian menunjukkan bahwa kemampuan literasi matematis dan kemandirian siswa yang diajar dengan model Discovery Learning berpendekatan RME -PISA tuntas secara klasikal dan lebih baik daripada siswa yang diajar dengan model RME, lebih baik daripada siswa yang diajar secara ekspositori.
\end{abstract}

Kata Kunci: Literasi Matematis, Kemandirian, Discovery Learning, RME

\section{PENDAHULUAN}

PISA (Program for International Student Assessment) merupakan organisasi penilaian tingkat internasional yang diselenggarakan tigatahunan dan disponsori oleh OECD (Organisation for Economic Co-operation and Development) yang beranggotakan 34 negara untuk mengetahui literasi matematis siswa yang berumur sekitar 15 tahun. Hal-hal yang dinilai dalam studi PISA meliputi literasi matematika, literasi membaca, literasi sains dan literasi keuangan. Hasil studi PISA (Program for International Student Assessment) tahun 2012 menunjukkan bahwa Indonesia berada pada peringkat ke-64 dengan skor 375 dari 65 negara peserta. Sementara, PISA mematok skor 494 untuk kemampuan rata-rata internasional.

Berdasarkan hasil PISA (Program for International Student Assessment) tahun 2009 [1], distribusi skor literasi matematika siswa Indonesia belum mencapai level 4 kaitan dengan soal-soal yang berhubungan dengan model untuk situasi yang konkret tapi kompleks dan mengintegrasikan representasi yang berbeda serta menghubungkannya dengan situasi nyata dimana 95\% siswa Indonesia memperoleh skor dibawah 493 yang termasuk dalam level 3. Untuk level 5 dan 6 tentang soal-soal penggunaan aljabar dalam kehidupan sehari-hari, merefleksikan kebenaran dari situasi yang disajikan atau pada penyelesaian yang diperoleh, serta menghubungkan unsur-unsur pada soal agar dapat menyelesaikan soal tersebut, hanya $0,1 \%$ siswa Indonesia mampu menyelesaikan soal untuk level teratas tersebut.

Permasalahan yang dihadapi guru matematika di SMA Kristen YSKI Semarang pada siswa kelas X tahun pelajaran 2014/2015 bahwa siswa pada umumnya memiliki kemampuan literasi matematis yang masih rendah. Khususnya bagi siswa yang pada dasarnya kurang tertarik belajar matematika, maka siswa siswa tersebut dengan sendirinya tidak memiliki keinginan untuk sungguh-sungguh mempelajari matematika dan tidak berusaha untuk meningkatkan kemampuan literasi mereka.

Pembelajaran yang masih berpusat pada guru dan kurangnya inovasi pembelajaran mempengaruhi kemandirian siswa-siswa di SMA 
Kristen YSKI Semarang. Dalam belajar dan aktivitas-aktivitas di kelas, siswa lebih banyak menunggu perintah dan arahan guru sehingga jika guru kurang memberi motivasi, siswa lebih banyak pasif. Siswa terbiasa belajar menerima informasi langsung dari guru tanpa menemukan sendiri, kurang mengembangkan ide dan gagasan, terbiasa mengerjakan soal yang berbentuk simbol dan angka sehingga ketika diberi soal berbentuk cerita dan terkait dengan dunia nyata, siswa mengalami kesulitan menginterpretasikan ke dalam bentuk mtematika.

Space and Shape merupakan salah satu konten dalam penilaian literasi matematis terkait dengan materi dimensi tiga yang difokuskan pada bagaimana menentukkan kedudukan titik, garis dan bidang dalam ruang dimensi tiga. Kriteria dan indikator yang akan dicapai dalam materi ini yaitu menentukan jarak titik ke titik, titik ke garis dan titik ke bidang, serta menentukan jarak garis ke garis dalam dimensi tiga. Geometri berkenaan dengan relasi ruang yang mempelajari tentang bentuk, ruang, komposisi beserta sifat-sifatnya, ukuran-ukurannya dan hubungan antara yang satu dengan yang lain.

Pada materi geometri siswa membutuhkan kemampuan visual yang relatif tinggi. Contohnya ketika siswa dihadapkan dengan permasalahan mencari panjang garis yang menghubungkan titik tengah 2 diagonal ruang suatu balok, saat itulah para siswa dituntut untuk membayangkan sebuah bangun yang nyata untuk bisa menyelesaikan masalah tersebut. Dalam hal ini, tidak hanya masalah kemampuan visualisasi tetapi pemahaman siswa tentang rusuk dan rangka juga ternyata bermasalah.

Model pembelajaran yang tepat dibutuhkan untuk mengembangkan kemampuan literasi matematis dan kemandirian siswa khususnya dalam pembelajaran jarak dalam ruang dimensi tiga. Discovery Learning merupakan suatu cara untuk mengembangkan cara belajar siswa aktif. Dengan menemukan sendiri, menyelidiki sendiri, maka hasil yang diperoleh akan setia dan tahan lama dalam ingatan, tak mudah dilupakan anak. Pengertian yang ditemukan sendiri merupakan pengertian yang betul-betul dikuasai dan mudah digunakan atau ditransfer dalam situasi lain
[2].Sintaks Discovery learning Menurut Muhibin Syah (2003) yaitu : (1) Stimulus; (2) Problem statemen; (3) Data collection; (4) Data Processing; (5) Verification; (6) Generalization.

Penelitian yang dilakukan oleh [3] menyimpulkan bahwa: pembelajaran di kelas eksperimen menggunakan Guided Discovery Learning berpendekatan Motivation to Reasoning and Proving Task meningkatkan kemampuan konstruksi bukti dan pemahaman bukti serta berpikir kritis mahasiswa khususnya untuk materi struktur aljabar. Penelitian [4] menyimpulkan bahwa peningkatan kemampuan analogi matematis siswa yang memperoleh pembelajaran dengan metode discovery lebih baik daripada siswa yang memperoleh metode pembelajaran dengan metode ekspositori. Penelitian yang dilakukan oleh [5] menyimpulkan bahwa ada perbedaan yang signifikan dari kelompok eksperimen yang diajar dengan metode Discovery Learning dibanding kelompok kontrol mengenai rata-rata prestasi akademik, dan persepsi inkuiri skor keterampilan, baik pada tingkat kognitif dan afektif.

Belajar matematika menurut pendekatan matematika realistik berarti bekerja secara matematik melalui memecahkan masalah yang berkaitan dengan kehidupan sehari-hari (contextual problem). Melalui contextual problem siswa membangun konsep matematika dari cara informal ke formal. Fase-fase model pembelajaran matematika realistik menurut [6] mengacu pada Gravemeijer, Sutarto Hadi, dan Treffers yang menunjukkan bahwa pengajaran matematika dengan pendekatan realistik meliputi : (1) Fase pendahuluan; (2) Fase pengembangan. Siswa mengembangkan atau menciptakan model-model simbolik secara informal terhadap persoalan atau masalah yang diajukan.; (3) Fase penutup atau penerapan. Melakukan refleksi terhadap setiap langkah yang ditempuh atau terhadap hasil pelajaran.

Penelitian yang dilakukan oleh [7] menyimpulkan bahwa pengembangan modul matematika realistik efektif untuk meningkatkan hasil belajar matematika pada peserta didik kelas $X$ SMK Negeri 3 Singaraja. Penelitian yang dilakukan oleh [8] menyimpulkan bahwa inovasi 
pembelajaran realistik dengan pendidikan karakter dan Asesmen PISA valid, praktis dan efektif untuk meningkatkan kemampuan pemecahan masalah siswa SMP dan meningkatkan karakter siswa secara baik.

TABEL I

SINTAKS DISCOVERY LEARNING BERPENDEKATAN RME

\begin{tabular}{|c|c|}
\hline Fase & Aktivitas Guru \\
\hline $\begin{array}{l}\text { Fase } 1 \\
\text { Pemberian } \\
\text { rangsangan/stimuli }\end{array}$ & $\begin{array}{l}\text { Kegiatan belajar dimulai dengan memberikan } \\
\text { pertanyaan yang merangsang berpikir siswa, } \\
\text { menganjurkan dan mendorongnya untuk membaca } \\
\text { buku dan aktivitas belajar lain yang mengarahkan } \\
\text { kepada persiapan pemecahan masalah. }\end{array}$ \\
\hline Fase 2 & Memberi kesempatan pada siswa untuk \\
\hline Mengidentifikasi & mengidentifikasi sebanyak mungkin masalah yang \\
\hline Masalah & $\begin{array}{l}\text { relevan dengan bahan pelajaran (memahami } \\
\text { masalah kontekstual), kemudian memilih dan } \\
\text { merumuskannya (mendiskripsikan) dalam bentuk } \\
\text { hipotesis (jawaban sementara dari masalah } \\
\text { tersebut). }\end{array}$ \\
\hline Fase 3 & Memberikan kesempatan pada siswa \\
\hline Pengumpulan data & $\begin{array}{l}\text { mengumpulkan informasi yang relevan sebanyak- } \\
\text { banyaknya untuk membuktikan benar tidaknya } \\
\text { hipotesis tersebut dan memilih model yang tepat } \\
\text { untuk menyelesaikan masalah. }\end{array}$ \\
\hline Fase 4 & Mengolah data yang telah diperoleh siswa melalui \\
\hline Pengolahan data & $\begin{array}{l}\text { kegiatan wawancara, observasi dan lain-lain. Data } \\
\text { tersebut kemudian ditafsirkan. }\end{array}$ \\
\hline $\begin{array}{l}\text { Fase } 5 \\
\text { Verifikasi }\end{array}$ & $\begin{array}{l}\text { Melakukan pemerikasaan secara cermat untuk } \\
\text { membuktikan benar tidaknya hipotesis yang } \\
\text { ditetapkan dan dihubungkan dengan hasil dan } \\
\text { pengolahan data }\end{array}$ \\
\hline
\end{tabular}

Fase 6

Generalisasi

Tujuan dari penelitian ini adalah untuk menginvestigasi apakah kemampuan literasi matematis dan kemandirian siswa SMA yang diajar menggunakan model Discovery Learning berpendekatan RME-PISA tuntas secara klasikal dan lebih baik dari siswa yang diajar menggunakan model RME dan lebih baik dari siswa yang diajar secara ekspositori.

Menurut Ausebel ada dua bagian dalam belajar yaitu belajar menemukan dan belajar menerima. Pada belajar menerima, siswa hanya menerima dan menghafalkan, sedangkan pada belajar menemukan, siswa menemukan sendiri konsep dan tidak menerima begitu saja. Pada pembelajaran menghafal, siswa menghafal materi/rumus yang sudah diperolehnya, tetapi pada pelajaran bermakna, materi/rumus dikembangkan dengan keadaan lain sehingga belajar lebih dimengerti. Menurut Bruner, dalam pembelajaran di kelas guru hendaknya memberikan kebebasan pada siswa untuk mengkonstruksi pengetahuannya berdasarkan benda konkrit yang diamati atau permasalahan dalam kehidupan sehari-hari siswa, untuk kemudian siswa berusaha menyelesaikan bermodalkan pengetahuan yang mereka miliki [9].

Vygotsky menyatakan teori pembelajarannya sebagai pembelajaran kognisi sosial (social cognition). Pembelajaran kognisi sosial meyakini bahwa kebudayaan merupakan penentu utama bagi pengembangan individu. Manusia mempunyai kebudayaan hasil rekayasa sendiri, dan setiap anak manusia berkembang dalam konteks kebudayannya sendiri. Oleh karenanya, perkembangan anak sedikit ataupun banyak dipengaruhi oleh kebudayaan, termasuk budaya dari lingkungn keluarga dimana anak berkembang [10]. Hipotesis dalam penelitian ini adalah Kemampuan literasi matematis siswa yang diajar dengan model Discovery Learning berpendekatan RME- PISA tuntas klasikal. Kemampuan literasi matematis siswa yang diajar dengan model Discovery Learning berpendekatan RME- PISA dan lebih baik dari siswa yang diajar dengan model RME, lebih baik dari siswa yang diajar secara Ekspositori.

\section{METODE}

Penelitian ini menggunakan desain eksperimen pretes-posttest control group design. Penelitian ini melibatkan 3 kelas sampel yaitu 2 kelas eksperimen dan 1 kelas kontrol. Dalam desain ini 3 kelas yang dipilih secara random, kemudian diberi pretest untuk mengetahui keadaan awal adakah perbedaan antara kelompok eksperimen dan kontrol. Kelas-kelas yang ada tidak dibentuk sendiri tapi menggunakan kelas yang sudah ada dan dipilh secara random. Pada kelas eksperimen 1 dilaksanakan pembelajaran dengan metode Discovery Learning berpendekatan RME - PISA (X1), kelas eksperimen 2 dilaksanakan pembelajaran menggunakan RME (X2) dan kelas kontrol (X3) diajar secara ekspositori. Pada akhir pembelajaran, siswa di ketiga kelas mendapat tes akhir yaitu tes kemampuan literasi matematis. Populasi penelitian ini adalah siswa kelas X SMA Kristen YSKI Semarang tahun ajaran 2014/2015 
yang terdiri dari 5 kelas dengan rata-rata siswa setiap kelas 21 orang. Sampel penelitian ini adalah siswa kelas XA, XB, dan XC dipilih dengan teknik simple random sampling, total sampel berjumlah 63 orang siswa.

Discovery learning dalam pembelajaran dilakukan secara berkelompok dimana siswa mengerjakan LKS yang telah disusun dengan model discovery berpendekatan RME sehingga soal-soalnya adalah soal cerita yang kontekstual. Pembelajaran ekspositori yang dimaksud disini adalah guru menjelaskan materi dan contoh soal dilanjutkan dengan latihan.

Kemampuan literasi matematis diukur dengan menggunakan tes esai. Indikator kemampuan literasi matematis adalah 7 komponen literasi dalam PISA yaitu : (1) Comunication, kemampuan mengkomunikasikan masalah (2) Modelling kemampuan membuat model matematika dari masalah atau dengan istilah lain Mathematising (3) Representation kemampuan untuk menyajikan kembali (representasi) dari suatu permasalahan, (4) Mathematics Reasoning and Argumentation, kemampuan menalar, memberi alasan dan kemampuan membuktikan sebuah pendapat (5) Problem Posing and Solving kemampuan menggunakan strategi untuk pemecahan masalah (6) Simbols and Formalism kemampuan menggunakan bahasa simbol (7) Mathematics Tools kemampuan menggunakan alat-alat matematika untuk memecahkan masalah [11].

Kemandirian siswa diukur melalui observasi selama proses pembelajaran berlangsug dengan indikator sebagai berikut: (1) Initiative (prakarsa); (2) Creativity (daya cipta); (3) Innovation (penemuan siswa); (4) Improvisation (pengembangan/penyempurnaan); (5) Pro-active (tidak pantang menyerah dalam mencari dan menemukan solusi berbagai masalah yang dihadapi) [12]

Pretest diberikan sebelum adanya perlakuan model dalam pembelajaran dengan tujuan untuk mengetahui kemampuan awal siswa pada kemampuan literasi matematis. Setelah iti diberiakn pembelajaran selama 4 kali pertemuan untuk setiap kelas, kemudian siswa mengerjakan soal posttest yang kisi-kisi dan perangkat soalnya sama dengan soal Pretest. Soal tes yang dipakai telah diujicobakan dan dilakukan analisis untuk melihat validitas, reliabilitas, tingkat kesukaran dan daya beda. Untuk lebih mempertajam analisis, siswa dikelompokkan berdasarkan kategori tinggi, sedang dan rendah dari hasil posttest.

Hipotesis ketuntasan klasikal dijawab melalui uji proporsi dengan KKM tuntas individu lebih dari 80 persen dari banyaknya siswa pada kelas tersebut. analisis menggunakan uji $\mathrm{z}$ dengan taraf nyata $\alpha=0,05$ ( Sudjana, 2012:234). Uji beda ratarata dimaksudkan untuk membandingkan rataan variabel kemampuan literasi matematis antara kelas eksperimen dan kelas kontrol. Dianalisis menggunakan uji ANOVA satu jalur dengan bantuan program SPSS.

\section{HASIL DAN PEMBAHASAN}

HASIL

Berdasarkan hasil skor pretest diperoleh kemampuan literasi matematis untuk siswa yang pembelajarannya menerapkan model Discovery Learning berpendekatan RME-PISA, model RME dan ekspositori menunjukkan hasil yang samasama rendah dan mengalami peningkatan pada saat posttest. Peningkatan dialami baik oleh siswa pada kategori tinggi, sedang maupun rendah.

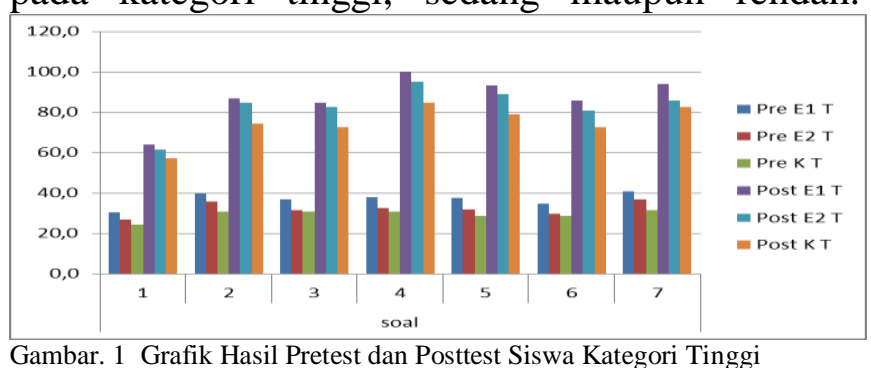

Hasil uji proporsi ketuntasan klasikal menunjukkan bahwa siswa yang diajar dengan model Discovery Learning berpendekatan RMEPISA, dan siswa yang diajar model RME yang mencapai tuntas individual telah mencapai ketuntasan klasikal lebih dari $85 \%$.

TABEL III

HASIL UJI PROPORSI KEMAMPUAN LITERASI MATEMATIS

\begin{tabular}{llll}
\hline Kelompok & Zhitung & Ztabel & Keterangan \\
\hline Eksperimen 1 & 2,52 & 1,64 & $\begin{array}{l}\text { Zhitung }>\text { Z0,5-0,05 } \\
\text { Tuntas Klasikal }\end{array}$ \\
Ekperimen 2 & 2,05 & 1,64 & $\begin{array}{l}\text { Zhitung > Z0,5-0,05 } \\
\text { Tuntas Klasikal }\end{array}$ \\
& & &
\end{tabular}




\section{A - - Jurnal Pendidikan Matematika Indonesia \\ Volum 1 Nomor 2 bulan September 2016. Halaman 43-49 \\ p-ISSN: 2477-5967 e-ISSN: 2477-8443}

Berdasarkan hasil uji normalitas dan homogenitas, diperoleh hasil bahwa kemampuan literasi matematis berdistribusi normal dan mempunyai kesamaan varian. Hasil uji hipotesis yang dilakukan diperoleh bahwa kemampuan literasi matematis dengan menggunakan Discovery Learning berpendekatan RME-PISA lebih baik dari pembelajaran dengan model RME dan lebih baik dari pembelajaran ekspositori. Perbedaan terletak pada nilai rata-rata dari setiap perlakuan yang diberikan.

TABEL IIIII

HASIL Uji NORMALITAS,HOMOGENITAS, UJI BEDA RATA-RATA DAN MEAN

\begin{tabular}{|c|c|c|c|}
\hline Kelompok & $\begin{array}{l}\text { Normalitas } \\
\alpha=\mathbf{0 , 0 5}\end{array}$ & $\begin{array}{l}\text { Homogenita } \\
S \\
\alpha=0,05\end{array}$ & $\begin{array}{l}\text { Uji Beda } \\
\text { rata-rata } \\
\alpha=0,05\end{array}$ \\
\hline \multicolumn{4}{|l|}{ Eksperimen 1} \\
\hline Eksperimen 2 & Sig $=0,169$ & $\mathrm{Sig}=0,770$ & $\begin{array}{l}0,000 \\
\text { (dilanjutkan }\end{array}$ \\
\hline Kontrol & & & $\begin{array}{ll}\text { uji } & \text { Post } \\
\text { Hoc) } & \end{array}$ \\
\hline $\begin{array}{l}\text { Eksperimen } 1 \text { dan } \\
2=\end{array}$ & & & Sig $=0,004$ \\
\hline $\begin{array}{l}\text { Eksperimen } 1 \text { dan } \\
\text { kontrol = }\end{array}$ & & & Sig $=0,000$ \\
\hline $\begin{array}{l}\text { Eksperimen } 2 \text { dan } \\
\text { kontrol }=\end{array}$ & & & $\operatorname{Sig}=0,001$ \\
\hline
\end{tabular}

Data tentang kemandirian siswa diamati di kelas eksperiman dan kelas kontrol pada setiap pertemuan setelah dirata-ratakan nilainya untuk kemudian didapatkan skor tertinggi dan disesuaikan dengan skala pada rating scale.

TABEL IV

DESKRIPSI MODEL PEMBELAJARAN DAN KEMANDIRIAN SISWA

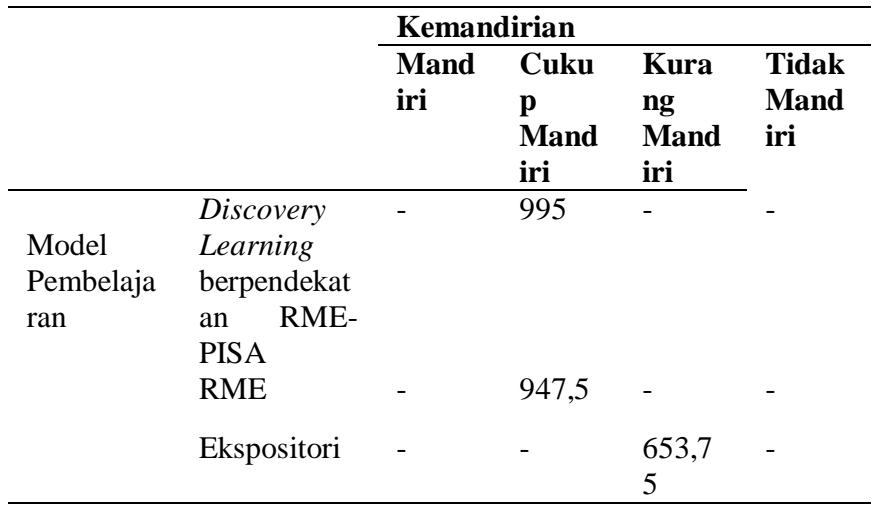

Pengembangan instrumen pengamatan kemandirian siswa didasarkan pada 5 Aspek yang kemudian dikembangkan menjadi 15 indikator pengamatan. Ke lima aspek tersebut antara lain : (1) Initiative (Prakarsa), (2) Creativity (daya cipta), (3) Innovation (pembaharuan/penemuan baru), (4) Improvisation (pengembangan/penyempurnaan),
(5) Pro-active. Berdasarkan hasil observasi maka peningkatan setiap aspek kemandirian disajikan dalam Gambar 2.

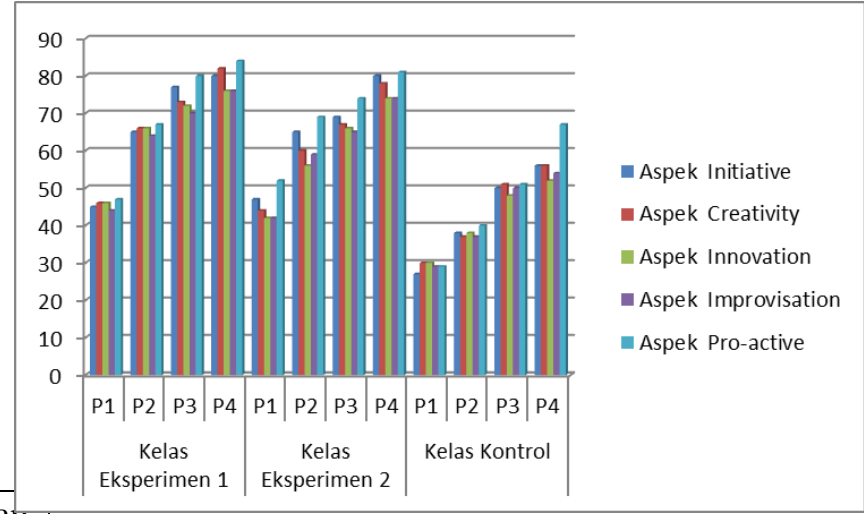

Meganthbar. 2 Peningkatan Aspek-aspek Kemandirian

Dari diagram terlihat bahwa adanya peningkatan 80kemandirian siswa dari pertemuan pertama sampai 74peytemuan ke empat. Sedangkan untuk peningkatan 66şॄఠ aspek, terlihat bahwa aspek Pro-active mengalami peningkatan yang lebih tinggi dibanding aspek yang lain.

PEMBAHASAN

Hasil uji z pada Tabel 2 sesuai dengan hipotesis penelitian yaitu kemampuan literasi matematis mahasiswa yang pembelajarannya menggunakan model Discovery Learning berpendekatan RMEPISA dan pembelajaran dengan model RME tuntas secara klasikal $(\mathrm{KKM}=70)$.

Hasil uji beda rata-rata menunjukkan rataan dari kelas eksperimen lebih tinggi maka dapat disimpulkan bahwa kemampuan literasi matematis dari siswa yang diajar menggunakan model Discovery Learning berpendekatan RME-PISA lebih baik dari kelas yang diajar dengan model RME dan lebih daik dari kelas yang diajar secara ekspositori.

Temuan penelitian ini mendukung hasil penelitian yang dilakukan oleh [13] dan [14] yang mengatakan bahwa pembelajaran dengan pendekatan Discovery lebih efektif dari ekspositori atau metode lain terhadap penerimaan siswa dalam proses belajar mengajar. Hal yang sama juga dikemukakan oleh [5] yang mengatakan bahwa ketika siswa dipaksa dengan pembelajaran secara tradisional, mereka kesulitan dalam memahami konsep-konsep mengenai subjek dan menghubungkan dengan pembelajaran sebelumnya. Hal ini terbukti dalam penelitian 
yang dilakukan oleh Balim, siswa yang diajar menggunakan model Discovery Learning lebih banyak menjawab benar daripada siswa di kelas tradisional (ekspositori) pada saat tes akademik. Hasil penelitian [8] menyimpulkan bahwa inovasi pembelajaran dengan model PMRI (RME) dengan pendidikan karakter dan penilaian PISA efektif untuk mengembangkan kemampuan siswa dalam pemecahan masalah matematika dibandingkan dengan kelas ekspositori.

Pembelajaran penemuan membantu siswa untuk mencari dan menemukan sendiri konsep utama dalam menghitung jarak yaitu konsep tentang garis tegak lurus terhadap titik, garis atau bidang yang kemudian disimpulkan sebagai jarak. Pembelajaran yang dikaitkan dengan masalah realistik semakin membuat siswa memahami bahkan mengingat lebih lama konsep yang mereka temukan.

Temuan penelitian untuk kemandirian siswa yang diajar dengan model Discovery Learning berpendekatan RME-PISA, RME dan ekspositori secara klasikal maka model Discovery Learning berpendekatan RME-PISA lebih baik untuk mengembangkan kemandirian siswa dibanding model RME atau ekspositori. Dengan demikian dapat disimpulkan bahwa pembelajaran dengan Discovery Learning dapat meningkatkan kemandirian siswa. Penelitian [5] yang mengatakan bahwa model pembelajaran Discovery Learning mengharuskan siswa untuk mengkomunikasikan konsep, informasi dan kasus melalui diskusi dan menjawab pertanyaan dan mendapatkan informasi itu sendiri. Itulah sebabnya siswa harus berpartisipasi di kelas dalam kelompok belajar agar lebih aktif dalam pembelajaran. Siswa yang diajar dengan model pembelajaran penemuan yang dilakukan dalam aktivitas kelompok dalam eksperimen memiliki persepsi dan ketrampilan belajar lebih baik dari siswa yang diajar secara tradisional/ekspositori.

\section{KESIMPULAN DAN SARAN}

KESIMPULAN

Berdasarkan proses dan hasil penelitian dapat disimpulkan bahwa siswa yang diajar menggunakan model Discovery Learning berpendekatan RME-PISA dan RME memenuhi ketuntasan klasikal pada batas $\mathrm{KKM}=70$ dan batas ketuntasan klasikalnya adalah lebih dari $85 \%$. Kemampuan literasi matematis dan kemandirian siswa yang diajar menggunakan model Discovery Learning berpendekatan RMEPISA lebih baik dari siswa yang diajar menggunakan model RME dan lebih baik dari siswa yang diajar secara ekspositori. Kemandirian siswa pada aspek pro-active lebih tinggi dibanding aspek prakarsa, aspek daya cipta, aspek pembaharuan/penemuan baru dan aspek pengembangan/penyempurnaan. Hal ini dikarenakan siswa lebih suka belajar dalam diskusi kelompok karena mereka bekerja bersama teman-teman dalam mencari dan menemukan solusi pemecahan masalah, berani menyampaikan pendapat dan aktif berkomunikasi menyelesaikan masalah.

Implementasi Discovery Learning berpendekatan RME-PISA mempunyai pengaruh yang baik terhadap peningkatan kemampuan literasi matematis dan kemandirian siswa, sehingga layak untuk digunakan sebagai model pembelajaran dalam matematika khususnya untuk materi geometri yang tergolong sulit diajarkan maupun dipahami.

SARAN

Guru-guru dalam pembelajaran di kelas hendaknya tidak selalu memberikan bentuk soal yang langsung pada bentuk matematika tetapi bisa memberikannya dalam bentuk soal cerita sehingga siswa terbiasa menyelesaikan soal-soal bentuk soal cerita juga dalam teknik penulisan soal, bentuk soal yang tidak seperti biasa dengan menggunakan kata "Hitunglah", "Berapakah", tetapi bisa menggunakan "Bagaimana perasaan anda tentang soal ini?" sehingga siswa terlatih berargumen dan memberi alasan. Komponen proses dalam literasi matematis PISA yang terdiri dari: (1) Mathematics Reasoning and Argumentation, (2) Mathematical Comunication, (3) Moddeling, (4) Problem Possing and Solving, (5) Representation, (6) Simbols and formalism, (7) Aids and Tools juga 6 level kemampuan dalam PISA hendaknya mendapatkan penekanan pada kegiatan pembelajaran. Penekanan tersebut dapat dilakukan 
dengan cara berikut: (a) Menjadikan ketujuh komponen dan 6 level kemampuan itu menjadi "warna" dalam pemberian soal-soal tugas maupun tes (b) Mengajak siswa untuk menelaah dan menggunakan kemampuan berpikirnya untuk bisa menganalisis setiap soal yang berdasarkan 7 komponen yang ada (c) Menjadikan 7 komponen dan 6 level kemampuan itu sebagai refleksi terhadap kemampuan literasi matematis siswa dalam upaya menaikan posisi Indonesia dalam tes PISA berikutnya dan yang lebih penting adalah meningkatkan kemampuan berpikir, bernalar dan berargumen dalam diri siswa.

\section{DAFTAR PUSTAKA}

[1] Stacey, K. 2010. "The View of Mathematical Literacy in Indonesia". Journal on Mathematics Education (IndoMS-JME), Volume. 2. Hal: $1-24$

[2] Suryosubroto. 2002, Proses Belajar Mengajar di Sekolah. Jakarta: Rineka Cipta.

[3] Isnarto. 2014. "Kemampuan Konstruksi Bukti dan Berpikir Kritis Matematis Mahasiswa pada Perkuliahan Struktur Aljabar Melalui Guided Discovery Learning Pendekatan Motivation to Reasoning and Proving Tasks ". Disertasi. Semarang: Program Pascaserjana UNNES

[4] Risqi dan Samsul. 2014. "Pengaruh Penggunaan Metode Discovery Terhadap Kemampuan Analogi Matematis Siswa Smk Al-Ikhsan Pamarican Kabupaten Ciamis Jawa Barat". Infinity Jurnal Ilmiah Program Studi Matematika STKIP Siliwangi Bandung, Vol 3, No.1.

[5] Balim, A. G. 2009. The Effects of Discovery Learning on Students Success and Inquiry Learning Skills. Eurasian Journal of Educationa Research, Issue 35, Spring 2009, 1-20.
[6] Wijaya, A. 2012. Pendidikan Matematika Realistik: Suatu Alternatif Pendekatan Pembelajaran Matematika. Yogyakarta: Graha Ilmu.

[7] Somayasa, W. Natajaya N. \& Candiasa M. 2013. "Pengembangan Modul Matematika Realistik disertai Asesmen Otentik Untuk meningkatkan Hasil Belajar Matematika Peserta Didik Kelas X di SMK Negeri 3 Singaraja". e - Journal Program Pascasarjana Pendidikan Ganesha Program Studi Penelitian dan Evaluasi Pendidikan. Vol. 3

[8] Wardono, \& Mariani, S. 2014. "The Realistic Learning Model With Character Education And PISA Assessment To Improve Mathematics Literacy". International Journal of Education and Research. Vol.2 No.7. Hal 361-372

[9] Suherman, E. 2003. Strategi Pembelajaran Matematika Kontemporer. Bandung: Jurusan Pendidikan Matematika Fakultas Pendidikan Matematika dan Ilmu Pengetahuan Alam Universitas Pendidikan Indonesia

[10] Suyono dan Haryanto. 2012. Belajar dan Pembelajaran. Bandung: PT. Remaja Rosdakarya.

[11] OECD, 2012. PISA 2012 Assesment and Analitytical Framework Mathematics Reading, Science, Problem Solving, and Financial Literacy. (online) (http://www.oecd.org diakses 8 Oktober 2014)

[12] Sumahamijaya, S. Dkk. 2003. Pendidikan Karakter Mandiri dan Kewiraswastaan (Suatu Upaya bagi Keberhasilan Program Pendidikan Berbasis Luas/ Broad Based Education dan Life Skill). Bandung : Angkasa Bandung

[13] Martins, O. O. dan Oyebanji, R. K. 2000. The effects of inquiry and lecture teaching approaches on the cognitive achievement of integrated science students. Journal of Science Teachers' Association of Nigeria. 35 (1\&2) 25-30.

[14] Bajah, S.T \& Asim, A.E . 2002. Construction and Science Learning Experimental evidence in a Nigerian Setting. World Council for Curriculum and Instruction (WCCI) Nigeria. 3 (1), 105-114. 